\title{
Gruppboende för dementa - en omsorgsform eller ett begrepp i försvinnande?
}

\section{ULLA MELIN EMILSSON}

Under ett tiotal år från 1980-talets mitt framstod gruppboende som den enda självklara omsorgsformen för dementa i vairt land. Alla kommuner med självaktning byggde gruppboenden i rask takt. Men så i mitten av 1990 upphörde denna utbyggnadsiver. Hur kan man förstå att ett sätt att ge omsorg till en viss grupp människor under en period är det enda rätta, för att sedan se ut att försvinna? I denna artikel diskuteras förändringen i praktiken och $i$ retoriken och betydelsen av det glapp som tycks råda mellan dessa två världar.

\begin{abstract}
Inledning
Avsikten med denna artikel är att beskriva och försöka förstå hur ett sätt att organisera och sörja för en grupp gamla, de dementa, under en viss period kan anses vara det

Ulla Melin Emilsson är fil.dr. i socialt arbete och universitetslektor vid Socialhögskolan vid Lunds universitet.
\end{abstract}

enda självklara omsorgsalternativet för att sedan utan synbarlig anledning se ut att försvinna. Genom en jämförelse mellan vad som sker i vardagsspråket (vad som där sägs om praktiken) och styrningsspråket (retoriken på beslutande nivå) diskuteras om och hur det glapp som tycks råda mellan dessa världar kan ha betydelse för vårdformens innehåll och fortlevnad. Utifrån hur perso- 
nalen själv uppfattar och beskriver denna del av äldreomsorgen, och hur den formuleras på papperet av de som planerar och bestämmer, hoppas jag kunna bringa ljus över det som händer.

För att tydliggöra ambitionerna tar jag hjälp av Mia Vabø (2003 s 63) när hon ställer det hon kallar för "vardagsspråket", det som kommer från de erfarenhetsbaserade berättelserna, i relation till "styrningsspråket» från administratörernas och planerarnas värld. Jag följer två huvudlinjer, den från det vardagliga arbetet med gamla demenssjuka och den från det utredande/myndighetsutövande sammanhanget. Sättet att använda benämningen gruppboende, men även begrepp som vård, omvårdnad, omsorg och boende placeras här i fokus. Det handlar med andra ord om hur man i Sverige talar om gruppboende som vårdform i arbetet med gamla demenssjuka människor och hur samma vardag beskrivs ur ett tjänstemannaperspektiv. Med en socialpsykologiskt orienterad ansats försöker jag begripa de fenomen som uppträder och hur det kan komma sig att de två språken inte tycks mötas. Utblickar mot hur praktiken och retoriken formas och formuleras i Frankrike, ett land med en erfarenhet betydligt längre än vår inom denna speciella vårdform, och Portugal där äldreomsorgen i allmänhet och demensvården i synnerhet bara är i början av sin utveckling, används för att ge ytterligare perspektiv på dessa fenomen som de visar sig i vår svenska vardag.

I försöken att få och ge en bild av hur denna vardagsverklighet uppfattas och omtalas har jag framförallt använt mig av frågor kring hur de som arbetar där beskriver den; vad säger personalen i denna vardag om den praktik de befinner sig i och vad säger de om hela gruppboendeidén som sådan? Och hur överensstämmer detta med hur det uttrycks av dem som bestämmer, i "styrningsspråket»? Vad anser man att man gör eller borde göra inom gruppboendets väggar? Ger man vård, omvårdnad, omsorg eller en kombination av detta? Eller är gruppboende bara en form av boende som beteckningen antyder?

\section{Metoder och material}

Det empiriska underlaget har sitt ursprung i huvudsakligen två typer av källor; tre egna tidigare och en pågående studie. De redan genomförda studierna innehåller dels deltagande observationer och handledning, dels intervjuer med sammanlagt 90 vårdbiträden och chefer. Samtliga projekt har, på ett eller annat sätt, haft fokus på gruppboenden i Sverige för gamla demenssjuka människor. Studierna har bedrivits under tio år från 1993 och framåt. En period som både sammanfaller med gruppboendeepokens blomstringstid men också dess avveckling och eventuella "försvinnande». De redan genomförda och dokumenterade studierna har haft olika syften och infallsvinklar (se Melin Emilsson 1996, 1998, 2001a,c, 2002, 2003a,b). Några frågor har emellertid återkommit och ställts till alla intervjupersoner i samtliga projekt. En av dessa är: »Hur ser du på gruppboende som vårdform för gamla demenssjuka människor? «. En del av dessa data har behandlats i sina respektive sammanhang, men här tas de upp och betraktas som svar på just denna fråga, både i förhållande till de tidigare undersökningarna, men också till den pågående studien. Denna tog sin början 2002

Ulla Melin Emilsson: Gruppboende för dementa - en omsorgsform eller ett begrepp i försvinnande? 
och utgörs av ett treårigt forskningsarbete där äldreomsorg i Frankrike och Portugal, med särskilt fokus på demensvård, jämförs med framförallt svenska förhållanden.

\section{Fyra projekt - 135 intervjupersoner}

Inom ramen för de tre avslutade projekten har 15 gruppboenden i södra delen av Sverige på olika sätt ingått i mina studier. Med skiftande utgångspunkter har jag närmat mig dessa miljöer genom observationer, deltagande observationer, handledning och intervjuer med personalen. För enkelhetens skull benämns dessa avslutade projekt fortsättningsvis efter sina respektive huvudfokus; "Gruppboendeprojektet", "Informationsprojektet» och "Handledningsprojektet«. Den pågående komparativa studien kallar jag "Europaprojektet». Sammanlagt i de fyra studierna har 135 personer intervjuats enligt följande tidsschema:
"Gruppboendeprojektet" pågick under åren 1993 -1998 som en delstudie i ett större tvärvetenskapligt projekt. ${ }^{1}$ Arbetet resulterade bland annat $i$ avhandlingen "Vardag i olika världar. Om dementa och vårdbiträden på tre gruppboenden" (Melin Emilsson1998). ${ }^{2}$ Sammanlagt 39 personer intervjuades, samtliga kvinnor. Intervjuerna skedde individuellt och hade halvstrukturerad karaktär. 16 av de intervjuade hade mindre än två års erfarenhet av arbete på gruppboende, medan de övriga hade arbetat från tre och ända upp till mer än 20 år i denna vårdform. Några av de slutsatser som kunde dras av detta forskningsarbete var att gruppboendena i studien präglades av just de förhållanden som verksamheten hade skapats för att undvika, nämligen passivitet och ensamhet för de gamla. Dessutom hade personalen, de tillrättalagda förhållandena till trots, mycket svårt att orka med sitt arbete.

"Informationsprojektet" genomfördes under 1999 - 2000. ${ }^{3}$ I framförallt informe-

Fig. I.

Tidsperioder och antal intervjupersoner för respektive projekt.

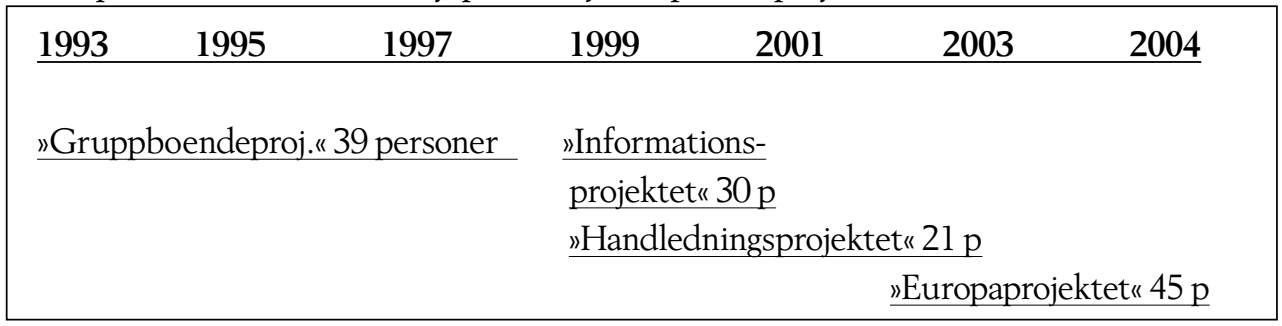

1 Projektet som hade titeln "Vård- och boendeformer för demenssjuka äldre. För vilka patientkategorier och hur ska gruppboende utformas? " bedrevs vid Institutionen för Klinisk Samhällsmedicin i Malmö med finansiering från SFR-Socialvetenskapliga forskningsrådet (SFR 93-0100-C-3C), Elmståhl mfl 1993.

2 Avhandlingsarbetet har genomförts inom ramen för SFR-stödda forskningsprogrammet "Äldreomsorgens vardag och villkor" vid Socialhögskolan i Lund (SFR 92-0312:3C).

3 Informationsprojektet har titeln "Vardag i olika världar - om att vara vårdbiträde bland dementa» och kunde genomföras med hjälp av medel från FRN- Forskningsrådsnämnden dnr 990001:139. 
rande syfte, vände jag mig till vårdpersonal i kommunalt baserad demensvård i fyra mindre skånska kommuner. Ambitionen var samtidigt att försöka ta reda på hur den yrkeskategori forskningen gäller, vårdbiträden inom kommunal demensvård, själva uppfattar och eventuellt använder såväl beskrivningar som slutsatser om sin egen yrkespraktik. Förutom två enhetschefer deltog vid två tillfällen fyra vårdbiträdesgrupper, med sammanlagt 28 deltagare. Intervjuerna genomfördes i grupp med en fokusgruppinspirerad ansats. Av dessa hade 11 vårdbiträden fem eller betydligt fler års erfarenhet från gruppboendearbete. $^{4}$

"Handledningsprojektet" är en interventionsstudie som bedrevs under åren 1999 - 2003. ${ }^{5}$ Mot bakgrund av den tidigare forskningen som hade visat att personalen inom denna vårdform hade svårt att orka med sitt arbete var huvudsyftet att undersöka om så kallad "yrkesinriktad processhandledning" kunde vara en användbar handledningsform för att ge vårdbiträden och arbetsledare utbildning och stöd i det vardagliga omsorgsarbetet. Förutom handledning användes deltagande observationer och individuella intervjuer som under-

4 Det som kom fram kan uttryckas i termer av : "Att känna igen men inte kännas vid» ( se Melin Emilsson 2003b).

5 Projektet har titeln »Handledning som utbildning och stöd för personal i arbete med äldre demenssjuka - ett utvecklingsprojekt» och genomfördes med stöd från RALF - Rådet för Arbetslivsforskning, 1999-0590) Vinnova dnr 2001/03584 och Samhällsvetenskapliga fakulteten vid Lunds universitet. sökningsmetoder. ${ }^{6} 15$ vårdbiträden deltog liksom sex enhetschefer. Ungefär hälften av deltagarna hade arbetat längre än fem år på gruppboende för dementa. ${ }^{7}$

"Europaprojektet" är en pågående studie som startade 2002 och beräknas fortgå fram till mitten av 2005. Bakgrunden kan till stora delar hänföras till de erfarenheter som de ovan nämnda projekten har givit mig och som i sin tur har väckt nya frågor. Framförallt var det en undran över hur det kan komma sig att klart uttalade och aldrig så välmenande ambitioner inte får avsedd effekt. Det övergripande syftet med denna studie är således att försöka förstå denna skillnad som kan råda mellan uttalade politiska mål för omsorgen om gamla demenssjuka människor och den verklighet de befinner sig i. Genom att även studera de socialpolitiska utgångspunkterna i två andra europeiska länder, Portugal och Frankrike, och hur målen förverkligas i det vardagliga omhändertagandet, är avsikten att försöka förstå de fenomen som har visat

6 Till skillnad från de övriga projekten som beskrivs, där jag själv har genomfört samtliga intervjuer, har Anna-Lena Strid, doktorand och anställd i projektet, här intervjuat de två vårdbiträdesgrupperna.

7 En slutsats av detta arbete är att handledning inte behöver vara något effektivt sätt att förbättra arbetet inom äldreomsorgen, men möjligen att få folk att trivas (och kanske stanna kvar) (se Melin Emilsson 2003a).

8 Projektet drivs med en treårig finansiering från FAS - Forskningsrådet för Arbetsliv och Socialvetenskap, Dnr 2001-2422 under titeln "Gammal och dement i Sverige, Portugal och Frankrike - en komparativ studie av socialpolitiska mål och implementering i tre kulturer». 
sig i vår svenska kultur och som bland annat tar sig uttryck i detta glapp mellan uttalade mål och faktisk tillämpning. Hittills har jag bland annat genomfört 26 individuella intervjuer och 7 gruppintervjuer med sammanlagt 19 deltagare. Erfarenheterna visar på förhållandevis små skillnader vad gäller de nationella socialpolitiska målen, men stora skillnader i sätten att organisera äldreomsorgen i sin helhet. Däremot kan man konstatera att ju närmare de gamla och deras vardagsverklighet man kommer, desto större är likheterna i sätten att utföra och tala om de faktiska omsorgshandlingarna.

\section{Val av metod}

Det faktum att jag har ställt samma fråga till alla de 90 intervjupersoner som ingår i de tre avslutade studierna och hittills till 45 i "Europaprojektet" gör det möjligt att åter formulera den som en "ny fråga» och vända mig till hela materialet. ${ }^{9}$ Valet av detta sätt att använda data, har till viss del sin grund i att alla de svar som jag har fătt, $i$ sig ytterligare har väckt min nyfikenhet, då fokus i de tidigare studierna inte enbart har behandlat just synen på boendeformen. Men det som kanske i ännu högre grad motiverar denna «återfrågning« är den kunskap som efterhand har växt fram och där tidsperspektivet är centralt, då studierna

9 De 24 som jag hittills har intervjuat i Frankrike har jag frågat om hur de ser på gruppboende som vårdform för gamla demenssjuka människor. I Portugal däremot har denna fråga knappast varit möjlig att ställa då vårdformen ännu inte finns och vars innebörd inte är känd vilket tydligt har framgått av svaren på de övriga intervjufrågorna. har pågått under den tid som fenomenet med "gruppboendeidéns uppgång och fall» har framträtt. ${ }^{10}$

Förutom en genomgående fråga innehåller alla intervjuer även samtal om de centrala begreppen. I vårdpersonalens redovisningar återfinns nämligen också deras sätt att se på och tala om vård, omsorg och boende för denna grupp av de gamla. I den meningen ger intervjuerna bilder av vårdpersonalens uppfattning om innebörden av gruppboende som vårdform, men också om deras syn på och upplevelse av praktiken som sådan, medan de deltagande observationerna kan sägas ge forskarens beskrivning av denna vardag. Genom att också ställa frågan till rapporter och dokument från statsmakternas sida försöker jag förstå om och hur de båda sammanhangens syn på och sätt att tala om gruppboende som vårdform möjligen påverkar varandra. ${ }^{11}$

10 Jfr de processinriktade dialektiska tankegångarna i den hermeneutiska cirkeln som innebär att man skapar en fördjupad förståelse av ett fenomen genom att studera pendlandet mellan helheten och delarna. Det man tidigare har lärt sig får en ny mening i ljuset av senare kunskap $i$ en aldrig upphörande cirkel (se $t$ e $x$ Alvesson \& Sköldberg 1998). Värt att nämna i detta sammanhang är emellertid tidsförskjutningens betydelse vad gäller såväl frågor som svar, då till synes likartade ordval och formuleringar kan ha olika innebörd beroende på i vilken tid och sammanhang de förekommer.

11 Kritiska diskursanalytiska resonemang av de språk som används ligger utanför ambitionerna med detta arbete. För fördjupning i detta se t.ex. Fairclough 1995. 


\section{Svårigheter på vägen}

När man använder sig av data som har samlats in under lång tid, inom ramen för olika projekt, stöter man på en rad svårigheter av metodkaraktär av vilka jag här nämner ett par. Tidsfaktorn, i den meningen att frågorna ställts under för den aktuella tiden rådande sociala och politiska sammanhang, är ett av dessa dilemman. Hur dessa förhållanden har inverkat på det empiriska materialet diskuteras visserligen kortfattat i artikelns senare del, men avsaknaden av en djupare analys kring detta får ses som en av begränsningarna i detta arbete.

Ett annat dilemma härstammar från de olika forskningsprojektens skiftande infallsvinklar. Av framförallt två anledningar har redogörelserna för de tidigare genomförda projekten därför fått en större plats än vad annars skulle ha varit motiverat. Ambitionen har varit att i någon mån försöka placera frågorna i sitt forskningsmässiga sammanhang och samtidigt ge en inblick i den grund som de tidigare projekten faktiskt utgör även för den aktuella studien.

\section{Gruppboende som idé}

För ungefär 25 år sedan startade i Sverige utvecklingen av en ny vård- och boendeform för en grupp av våra gamla, de demenssjuka. Den intensiva demensforskningen till trots hade man inte lyckats få fram några botemedel mot sjukdomen och idéerna till gruppboende som ett alternativ till den traditionella sjukhemsvården började växa fram. I diskussionerna och planeringen hade de terapeutiska tankegångarna en central plats och i mitten av 1980
- talet tog den stora utbyggnaden fart. Det sociala umgänget och relationerna till personalen utgjorde basen i denna nya vårdform där man genom anpassad fysisk miljö, aktivering och rätt bemötande inriktade sig på att åtminstone så långt som möjligt tillvarata och bibehålla det friska hos de dementa och göra tillvaron så dräglig som möjligt för dem (jfr Borell 1992, Gaunt m fl 1994). Tanken var att en väl avvägd hjälp i de dagliga sysslorna skulle kompensera de sviktande kognitiva funktionerna där minnesförlust är det mest framträdande. Hjälpen skulle ges i en hemlik miljö, där vanligen sex till åtta dementa skulle bo i egen lägenhet med gemensamma utrymmen för måltider och social samvaro. ${ }^{12}$ Ansvaret för vården av de gamla demenssjuka människorna vilade framförallt på sjukvården och hela idén skapades inom denna på sjukvård baserade ideologiska ram där gruppboende beskrevs som "ett kollektivt boende med förstärkta insatser av hemsjukvård" (Annerstedt 1988,1995). ${ }^{13}$ Under detta uppbyggnadsskede betraktades gruppboendet som en mellanvairdform mellan

12 För beskrivningar av de ursprungliga idéerna kring gruppboende som vårdform se $\mathrm{t}$ ex Annerstedt (1988, 1995), Nystrand (1994), Marcusson m fl (1995), Åhlund m fl (1995).

13 Inom den så kallade »Malmömodellen« utvecklades en anpassad vård- och boendeform mellan det egna hemmet och sjukhemmet. Liknande tankegångar prövades samtidigt även på andra håll på Baltzarsgården (se Beck-Friis 1988). Från det som 1985 startade som ett pilotprojekt hade det enbart i Malmö fram till starten av "Gruppboendeprojektet» sju år senare blivit 16 gruppboenden. Så såg det ut på många håll i landet.

Ulla Melin Emilsson: Gruppboende för dementa - en omsorgsform eller ett begrepp i försvinnande? 
det egna boendet och sjukhemmet. Tankegången byggde på en vårdstrategi innehållande dessa tre nivåer och en övertygelse om att de demenssjuka skulle flytta till den lämpligaste vårdformen efterhand som de blev sämre och hjälpbehovet ökade.

Utbyggnaden skedde i snabb takt under den andra halvan av 1980-talet och ca tio år framåt. 1987 bodde ca 500 av de dementa i gruppbostad, 1991 hade antalet ökat till ca 5100 och 1995 beräknades att av de då ca 100000 gamla demenssjuka människor bodde mellan 10000 och 14000 i gruppboende (se Socialstyrelsen 1995:2, Svensson m fl 1995, Wimo m fl 1994). Uppgifterna om antalet dementa, liksom antalet gruppboenden, kan emellertid variera ganska avsevärt beroende på vilken statistisk källa man vänder sig till. En starkt bidragande orsak till detta anses vara att det faktiskt saknas en gemensam och vedertagen begreppsapparat för de omsorgsformer som denna grupp gamla människor omfattas av (Socialstyrelsen 2002 s 12). En annan orsak till svårigheterna att få fram säkra uppgifter är att de dementa periodvis vårdas inom olika former av slutenvård inom ramen för olika huvudmäns ansvarsområden.

Om man som utgångspunkt väljer att använda sig av myndigheternas egna siffror och antaganden visar dessa att det år 2002 bodde 14000 gamla demenssjuka människor i det som då benämndes särskilda boenden (Socialstyrelsen a a). En jämförelse med motsvarande uppgifter från 1995 ger med andra ord vid handen att utbyggnadstakten under dessa sju år helt skulle ha avstannat. Detta samtidigt som antalet dementa under samma period antas ha ökat från ca 100000 till 133000.

\section{Frankrike som gruppboendeidéns vagga - Portugal dess motsats}

Sett i ett internationellt perspektiv är gruppboende för dementa en mycket begränsad företeelse. Förutom i Sverige finner man dess motsvarighet endast i Frankrike som brukar ses som föregångsland vad gäller utvecklingen av denna boendeform som där går under benämningen "cantou" (jfr Annerstedt 1995, se äv Ritchie $\mathrm{m}$ fl 1991, Colvez $\mathrm{m}$ fl 1994). Redan i slutet av 1960-talet utvecklades dessa administrativt autonoma lokaliteter som har fått stå som förebilder för den svenska gruppboendetanken. Dessa ursprungliga gruppboenden var insprängda i vanliga bostadsområden och hade stora likheter med många av de gruppboenden som senare kom att byggas i Sverige. Till skillnad från den svenska gruppboendemodellen hade de anhöriga i Frankrike i initialskedet en både aktiv och ansvarsfull roll i det dagliga arbetet.

Numera ingår även den franska gruppboendeverksamheten, i den begränsade omfattning den överhuvudtaget finns kvar, som särskilda avdelningar på de traditionella äldreboendena "Maison de Retraite». Innehållet $i$ vården har inga likheter med de ursprungliga tankegångarna om stöd $\mathrm{i}$ en så naturlig fysisk miljö som möjligt och aktiviteter i det dagliga livet. Idag är det bara demenssjukdomen som är kvar. Här bor och vårdas nämligen de gamla demenssjuka människor som inte längre varken kan gå, äta, sköta sin hygien eller kommunicera med omvärlden, annat än genom svaga skrik eller läten, $\mathrm{m}$ a o de allra mest sjuka 
och vårdkrävande, de som är sängliggande dygnet runt.

I Portugal däremot råder i detta avseende det motsatta förhållandet; gruppboende som idé är obekant. Särskilda vårdeller boendeformer för dementa finns inte överhuvudtaget och har heller aldrig funnits. Gamla människor med demensliknande symptom bor tillsammans med andra gamla på ålderdomshem eller sjukhem. Endast hos den nyligen startade Alzheimerföreningen i Lissabon möter jag anställda och anhöriga som talar om planer på att ordna särskilda boenden där man kan tillgodose de dementas behov av omsorg och ett aktivt liv.

\section{En bra vårdform - när den fungerar}

Vårdpersonalen i de tre avslutade studierna i Sverige har alla, på ett eller annat sätt, egna upplevelser av arbete på gruppboende. Genom att återge en del av deras erfarenhetsbaserade berättelser är ambitionen att ge inblick i hur gruppboende som vårdform kan uppfattas och beskrivas av de som befinner sig i denna vardag; i det som här benämns "vardagsspråket".

Gemensamt för det stora flertalet, av de 90 vårdbiträden och arbetsledare som har intervjuats, är den positiva inställningen till idén med gruppboende som vårdform. Däremot anser förhållandevis många, närmare bestämt 32 av de sammanlagt 79 tveklöst positiva, att den ursprungliga tankegången inte längre är möjlig att förverkliga. Ett sammandrag av hur svaren fördelar sig över tid visar dessutom tydligt hur de som uppfattar att det är »bra vårdform - men ej numera» efterhand ökar i antal. Detsamma gäller för fåtalet som uppger att de är tveksamma eller inte tycker att de har någon uppfattning. ${ }^{14}$

\section{Lugnt, hemlikt och mysigt}

När vårdpersonalen ger sina beskriv-

14 Tre uttrycker tveksamhet till vårdformen med hänvisning till att den »begränsade instängda miljön« är påträngande för både de gamla och personalen. De som »inte vet« är alla nyanställda.

Tabell I.

Vårdpersonalens syn på gruppboende som vårdform i de tre svenska studierna.

\begin{tabular}{|c|c|c|c|c|}
\hline Syn på vård-formen & $\begin{array}{l}\text { Gruppboende- } \\
\text { projektet (antal) }\end{array}$ & $\begin{array}{l}\text { Informations- } \\
\text { projektet (antal) }\end{array}$ & $\begin{array}{l}\text { Handlednings- } \\
\text { projektet (antal) }\end{array}$ & $\begin{array}{l}\text { Totalt } \\
\text { Antal vp }\end{array}$ \\
\hline »Bra vårdform《 & 25 & 17 & 5 & 47 \\
\hline $\begin{array}{l}\text { »Bra vårdform - men ej } \\
\text { numera« }\end{array}$ & 11 & 9 & 12 & 32 \\
\hline »Tveksam/vet ej« & 3 & 4 & 4 & 11 \\
\hline Totalt antal vårdpersonal & 39 & 30 & 21 & 90 \\
\hline
\end{tabular}

Ulla Melin Emilsson: Gruppboende för dementa - en omsorgsform eller ett begrepp i försvinnande? 
ningar av hur de ser på gruppboende som vårdform talar de i närmast lyriska ordalag. Ofta tar de sin utgångspunkt i hur de själva skulle vilja ha det som gamla och de jämför också med hur de vill att det skall kunna ordnas för deras egna föräldrar. Formuleringarna är ibland nästan ordagrant identiska från en del av de intervjuer i "Gruppboendeprojektet« som genomfördes 1993 och några av intervjuerna från »Handledningsprojektet« närmare tio år senare. Men även om innehållet i beskrivningarna har stora likheter så finns det ändå en avgörande skillnad; förhållandevis många av vårdbiträdena $\mathrm{i}$ "Gruppboendeprojektet« beskriver en vardagsverklighet som de själva upplever att de befinner sig i för tillfället, medan de andra talar om hur det var eller borde vara.

I de positiva berättelserna betonas den hemlika miljön, möjligheterna till aktiviteter och den väl tilltagna tiden. Ett av vårdbiträdena säger:

"Jag gillar söndagarna. När vi har gjort damerna fina $i$ håret, klätt dem $i$ något snyggt och lagat något extra gott till middan. Att då se hur nöjda de är. Och ibland kan man till och med att åka till kyrkan med några av dem. Då trivs jag som bäst ".

Andra jämför med hur stressigt det var i hemtjänsten, där många av dem har arbetat tidigare, och hur lugnt de tycker att de har det nu. "I början kändes det nästan overkligt lugnt här ibland, det var nästan så att man blev förslöad«. Men redan inom ramen för "Gruppboendeprojektet « framträder ett sätt att tala om gruppboende som innehåller vissa förbehåll. Samtidigt som man menar att vårdformen är bra förutsätter den inte enbart en stor personalstyrka utan även att de gamla flyttar därifrån när de inte längre har någon nytta av boendeformen: "Nu går det ju bra, men när de blir sämre måste de absolut flytta till sjukhem, annars faller hela idén«. Och bland dem som arbetat förhållandevis kort tid på gruppboende, och tycker att det fungerar bra, finns de som påpekar att det även finns nackdelar man inte får glömma. Någon jämför till exempel med ett fängelse där uteplatsen känns som en rastgård: "Men jag vet inte hur man skulle ordna det istället, så det här är väl det bästa ändå«.

\section{Kvarboendeprincipens fel}

I stort sett samtliga som anser att idén med vårdformen är bra - men att det inte längre ges möjlighet att förverkliga de ursprungliga tankegångarna - har alla arbetat minst 4-5 och ibland upp till 12 år på gruppboende. Många av dem började redan i början på 1990-talet när utbyggnaden och idéutvecklingen låg under sjukvårdens ansvarsområde. De har sedan upplevt vad de beskriver som stora förändringar i och med Ädelreformens genomförande och kommunernas övertagande av ansvaret 1992. Bland de som har arbetat kortare tid, särskilt i det nystartade gruppboendet i "Gruppboendeprojektet" uttrycks inte detta missnöje. Däremot hörs de besvikna rösterna i olika omfattning på alla de övriga boendena, oavsett när de har startat. Vad är det då de är så missnöjda över? Och hur förklarar de detta? I vardagsspråket är det framförallt tre omständigheter som återspeglas genom personalens berättelser; kvarboendeprin- 
cipen, resursbristen och ledarskapet. Av dessa ses vad de uppfattar som "kvarboendeprincipens införande» utan tvekan som det allra största hindret för förverkligandet av gruppboendetanken. Kritiken mot att de gamla demenssjuka skall bo kvar oberoende av demensgrad, hälsotillstånd och vårdtyngd förekommer lika kraftfullt i intervjuer från samtliga tre projekt. Berättelserna är dessutom slående lika i sina formuleringar oavsett under vilket år vi talar om detta, vilken kommun vi befinner oss eller vilket gruppboende det gäller. En i arbetsledande ställning säger:

"När vi fick det första gruppboendet i början på90-talet så hade vi ju världens förutsättningar. Det var åtta på det gruppboendet och vi fick så kallat (inom citationstecken) gamla i ungefär samma stadium av demenssjukdomen. Vi hade bra med personal, de lagade mat, de gjorde så mycket tillsammans och det var positivt tänkande frän personalens sida och de boende mådde bra. $J a$, det var liksom inga problem ibörjan. Problemen började sen när de utvecklade sina demenser olika och då begreppet kvarboendeprincipen infördes rasade alltihop."

Många beskriver att de känner sig lurade, att de har valt ett arbete utifrån vissa förutsättningar som inte längre finns kvar. "Det här är inte gruppboende längre. Det är mer som långvaird och jag har aldrig velat arbeta på långvården. Dessutom är det inte heller till någon nytta för de gamla när de är så dåliga att de inte kan delta $i$ några aktiviteter. «I positiva ordalag återges däremot vardagen som de kommer ihåg de första åren i början på 1990-talet: En av dem säger:
"Vi hade tid, vi kunde göra utflykter. Ja, vi var till och med till Danmark med några av dem. Då kunde man kalla det gruppboende . Men det finns också ett par undantag till alla dessa kritiska röster vad gäller kvarboendeprincipen. Ett par av dem hävdar att det är det enda rimliga alternativet för de gamla, att kvarboendeprincipen till och med är nödvändig för att de dementa skall kunna känna sig trygga i den miljö där de känner sig hemma.

\section{Bristen på resurser}

Resursbristen anses utgöra ett annat stort hinder för gruppboendetankens överlevnad. Till skillnad från de nyligen återgivna beskrivningarna vad gäller kvarboendeprincipen, och även den kommande redogörelsen som berör ledarskapet tas resurbristen knappast upp i "Gruppboendeprojektet«. ${ }^{15}$ Däremot uttrycker vårdpersonalen i både "Informationsprojektet» och "Handledningsprojektet» likartade funderingar kring detta. Framförallt märks denna brist på två sätt som de anser får avgörande konsekvenser för arbetets utförande. Det ena har att göra med bristen på gruppboenden. Det andra har sin grund i bristen på personal på de boenden som finns, både beträffande personaltäthet men också i svårigheten att

15 En del av förklaringen till detta kan antas ligga i de faktum att utbyggnaden av boendeformen fortfarande var under pågående och att personalstyrkan var i det närmaste dubbelt så stor som på gruppboendena såväl i »Informationsprojektet" som i »Handledningsprojektet». Fortsatt diskussion kring detta återkommer senare under analysdelen. 
rekrytera människor med utbildning som vill arbeta i vårdformen.

\section{Ledarskapet - ett bekymmer}

Det tredje stora hindret uppfattas ligga i det bristfälliga ledarskapet och även den organisatoriska strukturen. I många av gruppboendena (dock med ett par undantag) är vårdbiträdena mycket missnöjda med sin chefer. Dessa i sin tur är antingen besvikna på sina chefer högre upp i ledningen, på de organisatoriska förutsättningarna eller på bådadera. Missnöjet kan sägas ta sig likartade uttryck från vårdbiträden till enhetschefer och vidare till omsorgschefer. Det mest framträdande i denna kritik är bristen på målstyrning och ledaransvar:

"Allt flyter bara omkring. Den ena dagen gäller det ena, den andra dagen något helt annat. Ibland finns det inte pengar till att skaffa gallergrindar till sängarna så att de gamla inte ramlar ur, sen dyker det plötsligt upp dammvippor av äkta fjädrar. Då är det svairt att veta vad man skall rätta sig efter eller vad man skall tro."

\section{Från mellanvårdform till särskilt boende}

Som tidigare redovisats är berättelserna $\mathrm{i}$ "vardagsspråket" hämtade från intervjuer genomförda från 1993 och tio år framåt. Men många i personalgrupperna har erfarenheter av gruppboende som sträcker sig betydligt längre tillbaka än så. Mer än en tredjedel av dem har arbetat $\mathrm{i}$ vårdformen långt före Ädelreformens genomförande 1992. Några har både varit med i uppbygg- naden av nya gruppboendeenheter och deltagit i utvecklings- och forskningsprojekt i sjukvårdens regi. Vad sägs då i det språk som pågår parallellt med "vardagsspråket»? Det som används av de som planerar och bestämmer och här benämns "styrningsspråket»? Och hur ser beskrivningarna ut som har till syfte att vägleda och dra upp riktlinjer för gruppboendeverksamheten?

Genom att följa dokument, i form av utredningar, rapporter och kunskapsöversikter från andra hälften av 1980-talet till dags dato, är avsikten att försöka återge hur såväl begreppet gruppboende, som vårdformens innehåll, formuleras utifrån termer som vård, omvårdnad, omsorg och boende.

\section{Gruppbostäder-1990-talets lösning}

Genom en komplettering till bostadsförsörjningslagen ges kommunerna 1985 skyldighet att planera så »att alla, oavsett svåra funktionshinder, får en egen bostad av god kvalitet" (SoS-rapport 1991:5, s 13). Under 1987 intensifierar statsmakterna ytterligare sitt intresse för bostadsförhållandena vad gäller gamla, handikappade och långvarigt sjuka. Bostadsstyrelsen och Socialstyrelsen får då i uppdrag av regeringen »att göra en samlad redovisning av de kommunala planerna« i syfte att förbättra boendet för dessa grupper (a a s 8). I de rapporter som presenteras året därpå tas särskilt gruppboende upp »som ett alternativ till vistelse på institution" (a a). Gruppboende definieras som »ett litet antal fullvärdiga bostäder grupperade kring gemensamma utrymmen där omfattande service och vård kan ges dygnet runt». Bland utgångspunk- 
terna nämns att gruppboendeformen under några år har vuxit fram som ett alternativ till vistelse på institution, men också till vård i hemmet av människor med mycket stora omvårdnadsbehov. Detta utvecklingsarbete har framförallt skett inom ramen för sjukvårdens ansvarsområde. Som tidigare har beskrivits, finner man i bakgrunden till idéns uppkomst både en klart vårdstrategisk utgångspunkt, men också ett värnande om de dementa och deras anhöriga.

Från de styrandes sida uppfattas dessa erfarenheter från landstingens omsorgsverksamhet som en viktig kunskapskälla, men inför den vidare planeringen ger regeringen i maj 1989 Socialstyrelsen och Boverket $\mathrm{i}$ uppdrag att följa upp och analysera »de hittillsvarande kunskaperna och erfarenheterna av gruppboende för äldre människor" (SoS 1991:5, s 9). Gruppboende beskrivs som "...en form för vård och boende« som karaktäriseras av den egna lägenheten som den demente själv får inreda med sina egna möbler, de gemensamma utrymmena som ger den demente möjligheter till social träning och småskaligheten som ger förutsättningar för ett decentraliserat helhetsansvar för personalen (a a s 13). Vad gäller frågan om kvarboende framträder i rapporten två, i viss mån motsägande, förhållningssätt där det ena tar fasta på att "den enskildes rätt att få bo kvar i sin bostad till livets slut garanteras genom upplåtelseavtal" och det andra hänvisar till att den här typen vårdoch boendeformer mellan den egna bostaden och institution sannolikt kommer att vara nödvändiga inom demensvården.

Parallellt med detta utredningsuppdrag pågår sedan 1988 den så kallade äldredelegationens arbete $\mathrm{i}$ syfte att bland annat "...utarbeta ett förslag till närmare utformning av en förändrad ansvarsfördelning mellan huvudmännen inom samhällets äldreomsorg...«(Ds 1989:27 s 3). I uppdraget ingår också "att analysera behovet av medicinska insatser för äldre samt äldres behov av service och omvårdnad". I rapporten (a a s 65 ) skriver man att »...gruppboende kan för många vara ett bra alternativ till boende och vård på institution. Med gruppboende menas bostäder för ett litet antal personer som delar vissa gemensamma utrymmen och där det finns tillgång till stöd och hjälp dygnet runt «. ${ }^{16}$ I delegationens förslag ges kommunerna ett samlat ansvar som sammanfattas i begreppet "särskilda boendeformer för service och omvårdnad“. Detta omfattar servicebostäder, gruppboende, ålderdomshem och lokala sjukhem (a a s 75). Arbetet på gruppboende uttrycks i termer av sociala insatser och omvårdnad. Kopplingen till landstingens psykiatriska vård och somatiska långtidssjukvård betonas, medan begreppet omsorg inte nämns annat än i beteckningen »äldreomsorg".

Några år senare, den 1 januari 1992, träder den planerade Ädelreformen i kraft. Det övergripande syftet är att "skapa klara ansvarsförhållanden och ändamålsenliga organisatoriska förutsättningar för att utveckla samhällsinsatserna efter de målsättningar som riksdagen lagt fast ifråga om samhällets äldreomsorg“ (SOU 1996:2 s 20). De vägledande principerna uttrycks i ord som »självbestämmande och integritet,

16 Här redovisas också att huvudmannaskapet befintliga gruppboenden 1987 delas mellan kommunerna $34 \%$, landstingen $28 \%$ och delat ansvar $40 \%$. 
trygghet och valfrihet« (a a). Kommunerna får skyldighet att inrätta de ssärskilda boendeformerı som nämns i äldredelegationens slutrapport. I samband med detta beslutar riksdagen att statsbidrag skall utgå för watt stimulera en omfattande utbyggnad av gruppbostäder och andra alternativa boendeformer för äldre och handikappade» (a a s 55). Det är i föreskrifterna för dessa bidrag som den så kallade kvarboendeprincipen blir tydlig. I SOSF 1992:8, § 3 finner man följande formulering: "Bostäderna skall vara avsedda för permanent bruk och självständigt boende. I fråga om bostäder som skall upplåtas med hyresrätt skall det självständiga boendet garanteras genom hyresavtal av normalt slag".

I slutrapporten gällande Ädelreformen konstateras att antalet bostäder i särskilda boendeformer ökat betydligt, inte minst gruppboenden för dementa. Detta mycket tack vare de statliga stimulansbidragen. Dessa var planerade att utbetalas fram till december månad 1996 men under år 1995 tog de slut (SOU 1996:2, s 56). (Ett faktum som jag tolkar som en del i förklaringen till att den kraftiga utbyggnadstakten samma år helt upphörde.) Vad gäller innehållet i omsorgen skriver man:

"Socialstyrelsen anser att förutsättningarna för en god social äldreomsorg, dvs meningsfull vardag för de gamla och sjuka med funktionsnedsättningar är långt ifrån uppfyllda inom det särskilda boendet. Den kraftfulla ekonomiska àtstramningen i förening med en snabb medicinsk utveckling $i$ sjukhusvården är de huvudsakliga förklaringarna. Men också brister i verksamhetsinriktningen $i$ kommunernas äldreomsorg medverkar till att Ädelreformen ännu inte uppnått sina syften" (a a s 10).

\section{Gruppboende på 2000-talet}

När regeringen år 1989 ger Socialstyrelsen och Boverket i uppdrag att utreda frågan kring gruppboende för äldre är (som jag tidigare nämnt) en av orsakerna att man uppfattar sig ha ett alltför bristfälligt underlag för den fortsatta planeringen. När Socialstyrelsen tio år senare får i uppgift att följa utvecklingen av den nationella handlingsplan för äldrepolitiken, som 1998 antas av riksdagen, anges i "Slutrapport 2002« att kunskapen om särskilt boende för äldre fortfarande är oerhört begränsad. En starkt bidragande orsak uppges vara att det saknas men gemensam och vedertagen begreppsapparat och språkbruk på området" (a a s 12). Den stora utbyggnaden av gruppbostäder i samband med Ädelreformens genomförande och den utvärdering som presenteras i SOU 1996:2 tycks inte tillräckligt ha bidragit med den efterfrågade kunskapen. Ej heller verkar forskarvärldens studier från 1980-talets senare del och framåt - där både vården, omsorgen, boendet och organiseringen studerats - ha givit några kunskaper att använda sig av. ${ }^{17}$ Av slutrapporten framgår också att de traditionella benämningar som används ute i kommunerna för att beteckna olika typer av särskilda boenden är: gruppboende, servicehus, sjukhem och ålderdomshem, samt ibland på lokal nivå även äldreboende (a a s

17 Se t ex Annerstedt 1995, Eliasson-Lappalainen 1996, Fahlström 1999, Franssén 1997, Szebehely 1995, Öhlander 1996. 
61). Den samlade bedömningen är att handlingsplanen till trots - och de ökade statsbidragen - inte har medfört någon förbättring för de äldre och deras anhöriga. Tvärtom; de gamla får mindre hjälp, de anhöriga får ta större ansvar och det finns stora problem att få kompetent personal till vården och omsorgen.

En av de frågor som ställs är "varför behovet av särskilda boendeformer inte kan tillgodoses». I en nyligen presenterad kunskapsöversikt från februari 2004 presenterar Boverket och Socialstyrelsen resultatet av ett utredningsuppdrag från maj 2003 (Socialstyrelsen 2004-110-2). De konstaterar: „Det mest slående idag är att det sker en snabb avveckling av särskilt boende för äldre» (a a s 7). Som anledning till detta anges kommunernas svåra ekonomiska situation, vilken i sin tur leder till att de i stället försöker tillgodose behoven av vård och omsorg i den egna bostaden. Särskilt boende skall därför främst erbjudas dem som har ett mycket stort vårdbehov. Vad som explicit avses med särskilt boende framgår däremot inte. Under rubriken "Definitioner och begrepp" återfinns följande: "Särskilt boende för äldre avser särskilda boendeformer enligt 5 kap. $5 \S$ SoLı (a a s 11). Vänder man sig till Socialtjänstlagens text i 5 kap $5 \S$ finner man:

"Socialnämnden skall verka för att äldre människor fär goda bostäder och skall ge dem sombehöver det stöd och hjälp i hemmet och annan lättåtkomlig service. Kommunen skall inrätta särskilda boendeformer för service och omvårdnad för äldre människor som behöver särskilt stöd «.
Några närmare konkretiseringar av vad särskilt boende kan innebära ges med andra ord inte. Gruppboende som begrepp nämns överhuvudtaget inte i kunskapsöversikten, som i någon mening måste kunna uppfattas som en del av underlaget för den fortsatta planeringen av de äldres situation ifråga om vård och boende. Däremot kommenteras frågan om kvarboende: "Kommunernas 'kvarboendestrategi' för äldre innebär att man avvecklar äldreboenden och omvandlar servicehus till ordinära bostäder. Utvecklingen bygger på att man tillämpar striktare krav på biståndsbedömningen, vilket innebär att en plats i särskilt boende erbjuds först vid mycket omfattande vårdoch omsorgsbehov" ( Socialstyrelsen 2004110-2 s 50).

I Äldreberedningens slutbetänkande SENIOR 2005 behandlas en del av begreppen på ett likartat sätt; i stället för att redogöra för vad som avses med exempelvis särskilt boende hänvisas till gällande lagtext (SOU 2003:91, 32). ${ }^{18}$ Vad gäller innehållet i den hjälp de boende kan få återfinns en rad definitioner av ord som exempelvis omvårdnad, omsorg samt begreppsparet "vård och omsorg" (a a ss 32 -34). Gruppboende tas inte upp explicit. Däremot förs en diskussion kring kvarboendeprincipen där gruppboende nämns. Om kvarboendeprincipen sägs att den sedan 1970-talet varit den rådande ideologin inom äldreomsorgen, men att den dock inte är »entydigt definierad i vare sig förarbeten eller lagtext« (a a s 12). Två innebörder presen-

18 SENIOR 2005 fullständiga titel är: "Äldrepolitik för framtiden. 100 steg till trygghet och utveckling med en åldrande befolkning"

Ulla Melin Emilsson: Gruppboende för dementa - en omsorgsform eller ett begrepp i försvinnande? 
teras: den ena handlar om att få bor kvar och få hjälp i sin bostad, den andra om att få bo kvar även när man blir sämre och bor på särskilt boende. I den redogörelsen för olika konsekvenser av kvarboendeprincipens tillämpning berörs problemet med »...den äldre som vid flyttning till särskilt boende är $\mathrm{i}$ behov av så omfattande vård och omsorg att han eller hon inte kan dra nytta av den vård och omsorg som kan erbjudas vid vissa vård- eller boendeformer. Det kan $t$ ex gälla för personer med långt framskriden demenssjukdom som flyttar till gruppboende som främst är inriktat på att tillgodose behov i ett betydligt tidigare skede av sjukdomen.«(a a s 123).

Hur de dementas behov "i ett betydligt tidigare skede» uppfattas och på vilket sätt gruppboende som vårdform skall tillmötesgå dessa anges inte. I rapporten som helhet betonas i stället autonomi, valfrihet och de anhörigas ansvar. De s k "fyra nycklarna" i diskussionsbetänkandet Riv ålderstrappan! (SOU 2002:29): „Riv ålderstrappan, bryt åldersbarriärer, planera för ett aktivt åldrande och stärk ömsesidigheten« tyder snarast på en inriktning för den fortsatta äldreomsorgen mot de aktiva och pigga, de som befinner sig utanför vår diskussion kring kvarboende eller gruppboende.

\section{"Vardagsspråket" och "styrningsspråket"}

Från en studie av den nordiska hemtjänsten redovisar Vabø (2003 s 63) erfarenheter som för henne framstod som möten med en tvåspråkig värld "- en värld där administratörer och planerare talar ett språk och personal och arbetsledare ett helt annatw. Hon menar att det handlar om två språk styrningsspråket och vardagsspråket - som tenderar att förmedla helt skilda bilder av vad i hennes fall hemtjänsten är, men också borde vara. De två språken uppfattas som olika till sin karaktär och styrningsspråket upplevs som mera abstrakt och kontextlöst. Hon ställer sig bland annat undrande till vilken betydelse det får när de som planerar och bestämmer talar på ett annat sätt än de som omfattas av besluten.

Utifrån mina syften att dels undersöka om det är gruppboende som begrepp eller vårdform som håller på att försvinna, dels försöka begripa glappet mellan de två språken och dess eventuella betydelse för omsorgen av de dementa, ställer jag nu inspirerad av Vabøs tankegångar, motsvarande frågor till det presenterade materialet: Vilken karaktär kännetecknas de båda språken av? Hur beskrivs gruppboende som vårdform? Vilka är de centrala begreppen? Hur påverkar de båda språken och glappet mellan dem eventuellt varandra?

\section{Karaktär och innehåll}

De två språken, vardagsspråket och styrningsspråket, är helt olika till sin karaktär och kan i den meningen sägas representera två helt olika världar. Till skillnad från Vabøs (a a) erfarenheter finns det däremot stora likheter i de bilder som ges av samma vardag, medan skillnaderna ligger i de slutsatser man väljer att dra av det man ser. Jag uppfattar vardagsspråket som tydligt, direkt och oförändrat över tid. De som intervjuades under 2003 använder sig av ett mycket likartat språk, med i det närmaste 
identiska formuleringar, som de som intervjuades tio år tidigare. Bilderna är talande och exemplen från vardagens innehåll är nästan förvånansvärt lika. Även synen på vad ett gruppboende för dementa är eller borde vara är nästan ofattbart konstant utifrån de stora förändringar i förutsättningar som skett under tiden. Man talar ändå om gruppboende som en bra vårdform i hemlik miljö, med nära relationer och aktiviteter.

Styrningsspråket däremot är, till skillnad från vardagsspråket, för det mesta otydligt och mycket föränderligt. Otydligheten är successivt tilltagande. Språket blir med åren alltmer grått $\mathrm{i}$ den meningen att det är svårt att urskilja nyanser och innebörder. I början på 1990-talet (i exempelvis SoS 1991:5, s 9 som tidigare presenterats) ges en ingående redogörelse vad man anser karaktäriserar ett gruppboende; den egna lägenheten, de gemensamma utrymmena och småskaligheten. Dessutom ges förklaringar till varför just dessa faktorer anses väsentliga för gamla demenssjuka människor. Efterhand blir dessa motiveringar allt färre och i SENIOR 2005 redovisas inga sådana beskrivningar. Detta avspeglar den ena aspekten av förändringen på vad man i kommunikationsteoretiska termer kan beteckna som budskapets "processnivå", $\mathrm{m}$ a o hur något förmedlas. Den andra stora förändringen avser vad som sägs på den s k »saknivån", m a o budskapets innehåll. ${ }^{19}$ Från andra hälften av 1980-talet och fram till mitten av 1990-talet talar man om gruppboende i förhållandevis positiva ordalag, även om detta efterhand minskar

19 För kommunikation utifrån sak och processnivåer se t ex Olsson 1998. och blir svårare att upptäcka. I dagens styrningsspråk, med en begreppsapparat kännetecknad av otydlighet, går det emellertid inte att urskilja några ställningstaganden om vårdformen som sådan, vare sig $\mathrm{i}$ den ena eller andra riktningen.

\section{"Tydligt och oföränderligt" eller "otydligt och föränderligt"}

Även om de två språken i någon mening tycks »leva sitt eget liv« tänker jag mig att det är i den mellanmänskliga interaktionen som de utvecklas och vidmakthålls. Utgångspunkten är att människor påverkar och påverkas i möten med varandra och att det i varje grupp bildas ett tryck mot den enskilde medlemmen att anpassa sin uppfattning till den dominerande bilden (jfr t ex Michela 1996, Olsson 1998). Och till stor del sker detta genom orden. Ett sätt att försöka begripa de två språkens skilda karaktär kan vara att använda Alvessons (1989 s 24) beskrivning av en sociologisk och en psykologisk infallsvinkel på den socialpsykologiska förståelsen. Vardagsspråkets "tydlighet och oföränderlighet" skulle då kunna begripas utifrån socialpsykologins psykologiska inriktning där människans tidiga utveckling är central och agerandet blir tämligen självständigt i relation till samhälleliga förhållanden. I det perspektivet får tidsförskjutningen också mindre betydelse. Det faktum att de dementas behov av vård inte heller torde vara särskilt föränderligt över tid, oavsett skilda samhälleliga strukturer, skulle ytterligare kunna stärka detta kvarhållande i språket och bilden av det ideala gruppboendet. 
Styrningsspråkets "otydlighet och föränderlighet« skulle kunna hänföras till den sociologiska infallsvinkeln där socialisationen, liksom agerandet, förstås utifrån hur samhället och olika institutioner, som t ex arbetslivet, utövar en påverkan på människors sätt att handla. Till skillnad från vårdpersonalens vardag tillsammans med omsorgsbehövande dementa, befinner sig politikerna och tjänstemännen i en värld av implicit uttalade politiska och ekonomiska mål som de förväntas medverka till att förverkliga. Ett situation som $i$ sig kan antas förutsätta både otydlighet och ständig föränderlighet i språket. Utifrån detta synsätt får den tidsperiod materialet avser också betydelse, bland annat beroende på vilka socialpolitiska och strukturella omständigheter som för tillfället råder.

\section{I glappet mellan två världar}

Att med vetenskaplig ambition få grepp om och insyn i det glapp som verkar råda mellan vardagsspråkets och styrningsspråkets värld kan tyckas i det närmaste omöjligt. Men diskussionen om de två språkens karaktär visar, som jag ser det på avgörande skillnader i de två världarnas viljeyttringar, vilket leder till att dessa varken kan eller kanske vill mötas. Medan vårdpersonalen vill ha kvar vårdformen och resurserna, både för de dementas bästa men också för sin egen skull, vill politikerna göra nedskärningar under förespeglingar om bättre omsorg byggd på den enskilda människans valfrihet, autonomi och integritet. En ekvation som åtminstone för mig blir besvärlig att lösa, särskilt som just svårigheten att göra egna val tillhör ett av demenssjukdomens främsta kän- netecken. Genom att belysa den skiftande innebörd som läggs i vissa centrala begrepp, vill jag ändå försöka komma ytterligare en bit på vägen i försöket att både beskriva och förstå dessa fenomen.

\section{Begreppens skiftande innebörd}

Om vi börjar med beteckningen för den företeelse som undersöks; gruppboende, så kan vi konstatera att begreppet fortfarandet aktivt lever kvar i vardagsspråket, både bland dem som ingår i mina studier och ute i landets kommuner. Däremot ställer jag mig undrande till om det någonsin har använts $\mathrm{i}$ samma betydelse i styrningsspråket. Otydligheten och de svepande formuleringarna medför att man inte, annat än undantagsvis, kan avgöra vad som faktiskt menas med gruppboende (de få gånger ordet används). Vardagsspråkets detaljerade beskrivningar ger däremot en mycket klar bild som helt överensstämmer med sjukvårdens ursprungliga idéer om gruppboende som en mellanvårdform. En vårdform som dock anses omöjlig att vidmakthålla i och med den s k kvarboendeprincipens införande $\mathrm{i}$ samband med Ädelreformen. I styrningsspråket uttrycks däremot att kvarboendeprincipen har varit en ideologisk ståndpunkt från beslutsfattarnas sida ända sedan 1970-talet, även om detta inte finns reglerat i någon lagtext annat än genom besittningsrätten i de gamlas hyresavtal.

Försöker vi följa de begrepp som används för att beteckna vårdformens innehåll, $\mathrm{m}$ a o vilken typ av arbete som utförs på ett gruppboende, blir skillnaderna mycket stora mellan de två språken. När vårdpersonalen 
talar om vad de gör, förutom de dagliga hushållssysslorna, säger de att de hjälper, ger stöd till eller aktiverar de gamla. Ordet vård förekommer ibland, men då för att beskriva vad de gör (men inte vill göra) som liknar sjukhemsarbete eller långvård. Begreppen omvårdnad eller omsorg förekommer aldrig, vare sig i det intervjumaterial som återspeglas i vardagsspråket eller i de övriga situationer som utgör underlag i mina tre studier.

Styrningsspråkets begreppsanvändning med avseende på vårdformens innehåll följer inga för mig begripliga grunder. De vanligast förekommande orden är vård, omvårdnad och service. Ibland också sociala insatser men ytterst sällan omsorg, annat än i ordet äldreomsorg. Olika kombinationer finns också såsom »service och vård", "sociala insatser och omvårdnad", "service och omvårdnad" eller det allra senaste begreppsparet i SENIOR 2005; "vård och omsorg" som definieras som ett samlingsbegrepp inom äldrepolitiken (möjligen i syfte att ersätta ordet äldreomsorg?).

Så vitt jag förstår har styrningsspråket inte tagit intryck av det arbete man inom omsorgsforskningens område, under en rad av år, har lagt ner på att förstå denna vardag liksom att utreda och definiera dess begrepp. ${ }^{20}$ Även om omsorg, vård och omvårdnad uppfattas ligga mycket nära varandra och inte sällan används synonymt både i dagligt tal och i vetenskapliga sammanhang, har ordet omsorg en central plats inom äldreomsorgen. Szebehely (1996 s 22) skriver:» Omsorg säger något om vad som

20 Stina Johansson (2001) ger i sin bok "Den sociala omsorgens akademisering" en ingående diskussion kring kunskapens kärna i omsorgsarbetet. görs, om relationen mellan de inblandade parterna och kvalitén i arbetet«. Vård har enligt hennes mening starkare medicinska associationer än omsorg. Omvårdnad är i forskarnas värld förbehållet sjuksköterskornas perspektiv.

\section{Två parallella språk - två ideologier?}

Som tidigare beskrivits återges en och samma vardagspraktik med olika ord och på olika sätt i vardagsspråket och i styrningsspråket. Men skillnaderna kanske inte är så stora som de till förstone synes vara. Det kanske till och med råder den sortens likhet där man i någon mening uppfattar att man är överens, en likhet som medför att man accepterar den andres sätt att tala - utan att bry sig om att försöka påverka eller låta sig påverkas. I båda språken betonas nämligen bristerna i omhändertagandet av de gamla, de ekonomiska problemen och svårigheterna att finna kompetent personal. Men, det som skiljer dem åt är till viss del förklaringarna till problemens uppkomst och framförallt tankarna kring hur dessa skall lösas. Vardagsspråket håller fast vid den ursprungliga gruppboendeidén, medan styrningsspråket utreder, planerar och laborerar utifrån andra begrepp med annan innebörd. I den meningen tycks de två språken inte påverka varandra. Däremot påverkas vardagen för de gamla - till det sämre. Ett faktum som man är helt överens om i båda språken. Hur kan man då förstå att vårdpersonalen fortfarande talar om gruppboende utifrån de tankegångar som väcktes för mer än 20 år sedan? Och hur kan man samtidigt begripa att beslutsfattarna inte gör det? 
I min strävan att begripa det som händer vänder jag för en stund tillbaka och startar vid tiden för gruppboendeidéns uppkomst. För att visa på några av de fenomen som framträder i de två språken återger jag, i mycket fria ordalag, min egen tolkning genom en bild av ett tänkbart scenario.

Det sena 1970- och tidiga 1980-talet präglas av efterdyningarna frän några decennier av ekonomisk uppgång. Då uppstår inom sjukvården en vårdkris. Medellivslängden ökar, de gamla blir allt fler och därigenom får vi också fler dementa. De upptar snart alla vårdplatser på både sjukhem och inom långvård. Och de anhöriga orkar inte längre ta hand om dem. I bristen på de efterlängtade forskningsresultaten, som både skall förklara orsaken till demenssjukdomarna och leda fram till de botande medicinerna, föds (med förebilder frän Frankrike) idén till gruppboende som vårdform. Ett helt nytt synsätt växer fram. Både det privata boendet och vårdens innehåll blir centralt. Tillvaron för de dementa (och deras anhöriga) skall bli bättre samtidigt som sängplatser frigörs. Dessutom till en lägre kostnad. De nya idéerna får fotfäste på ett par ställen $i$ landet, där de drivs fram av de riktigt stora entusiasterna. Projektpengar söks, personal utbildas och inom loppet av några air har en i det närmaste reformlik rörelse med närmast ideologiska förtecken tagit fart. Det forskningsmässiga intresset för denna nya företeelse finns företrädesvis inom sjukvården. ${ }^{21}$. Demensdiagnosen, symptomen och bemötandet har centrala positioner.

21 Se t ex Adolfsson m fl 1991, Hallberg 1990, Bauer Alfredsson 1991.
Omhändertagandet beskrivs som vård och de arbetsledande funktionerna innehas av sjuksköterskor. De övriga går oftast under beteckningen vårdare. Ordet omsorg nämns överhuvudtaget inte.

Då, $i$ slutet av 1980-talet, startar diskussioner om samarbete mellan huvudmän, samlat ansvar och helhetsgrepp. 1992 genomförs Ädelreformen och ansvaret för omsorgen om de gamla blir kommunernas. Sjukvairdens syn på de "dementa som sjuka" byts ut mot de "dementa som gamla". Gruppboendet skall erbjuda boende men inte sjukvaird. Liksom andra gamla och sjuka skall de dementa söka hjälp inom distriktsvården. På gruppboendet är vårdbiträdenas uppgift att ta hand om de gamla, bemöta dem väl och aktivera dem. Vårdstrategin $i$ tre nivåer sägs bli ersatt av den så kallade kvarboendeprincipen. Demensgrad och hälsotillstånd skall inte längre vara styrande. I stället skall man låta de gamla bo kvar på gruppboendet så länge det överhuvudtaget är möjligt och helst skall de fä dö "hemma" $i$ den sista egna bostaden. Och så såg den nya ideologin dagens ljus.

Vad som "egentligen" pågår i dessa två språk, i två världar som inte tycks mötas, får vi antagligen aldrig veta. Ej heller hur detta faktiskt har påverkat omsorgen om gamla demenssjuka människor. Men av styrningsspråket framgår att kvarboendeprincipen fanns med redan från början. Förutsättningarna för gruppboende enligt de ursprungliga tankegångarna som en mellanvårdform, har därmed faktiskt aldrig funnits. Men av någon anledning fortsatte man, att även på de gruppboenden som startade efter 1992 presentera mellanvård- 
formen som ett faktum. Hur det kommer sig att det har blivit så här och hur det har gått till kan varken mina empiriska data eller genomgången av administratörernas och beslutsfattarnas dokument ge svar på. Men, jag vill i alla fall som avslutning förmedla några ytterligare reflektioner kring hur jag tänker kring fenomenet med gruppboendets "uppgång och fall" och hur detta fenomen blev synligt för mig i kontakten med den franska äldreomsorgens vardag.

\section{Avslutande utblick och reflektioner ${ }^{22}$}

En av anledningarna till att jag började intressera mig för att jämföra omsorgen om gamla demenssjuka människor i Frankrike och Portugal - med förhållandena i Sverige var att just dessa två länder kan sägas representera två ytterligheter inom demensvårdens område. Frankrike var först i världen att redan på 1700-talet vetenskapligt dokumentera begreppet demens och sedermera (som jag tidigare har beskrivit) skapa den första gruppboendeformen "cantou". Portugal är ett av de länder där de dementas situation knappast uppmärksammats överhuvudtaget.

Med spänd förväntan såg jag fram emot att inom ramen för "Europaprojektet» få ta del av vårdformens utveckling i whemlandet» Frankrike. Men bland de tio enheter

22 För värdefulla synpunkter i arbetet med denna artikel vill tacka deltagarna i den seminarieverksamhet som bedrivs inom forskningsprogrammet "Äldreomsorgens Vardag och Villkor" och som leds av Rosmari Eliasson-Lappalainen vid Socialhögskolan i Lund. jag hittills har besökt har det varit svårt att finna några gruppboenden överhuvudtaget. Och det fåtal jag har funnit (närmare bestämt två) med beteckningen "cantou", är närmast att likna vid våra gamla långvårdsavdelningar. När jag vidare har ställt frågor kring "gruppboende som vårdform" har det visat sig att endast två av de 24 som jag har intervjuat känner till den ursprungliga idén. Och trots att dessa två har arbetat inom den franska äldrevården sedan mitten av 1960-talet, kan de varken dra sig till minnes hur omvandlingen från cantou till långvård har gått till, eller när förändringen började. Hur retoriken i det franska styrningsspråket har utvecklats under samma tid återstår för mig att undersöka.

Det var i mötet med det franska "vardagsspråket« jag började fundera över om det inte är något motsvarande som håller på att inträffa i Sverige; att begreppet gruppboende finns kvar, men i praktiken står det för en helt annan vårdform än den ursprungliga. Fenomenet med vårdpersonalens nästan krampaktiga vidhållande vid beteckningen $i$ sig, går möjligen att till viss del begripa utifrån de ideologiska inslag jag uppfattar finns med i den ursprungliga idén. ${ }^{23}$ Genom att skapa en helt ny vårdform där positivt laddade attityder och värderingar kopplas till en speciell begreppsapparat, utvecklas med hjälp av språket en sammanhållande länk i vardagens retorik som inte nödvändigtvis behöver överensstämma med innehållet $\mathrm{i}$

23 För innehållet i begreppet ideologi se t ex Egidius 1994. Jfr även Vabø (2003 s 66) när hon beskriver begreppsfästandets och språkets betydelse för förändringen i samband med nya reformer. 
praktiken. Styrningsspråket å sin sida har samtidigt sin egen retorik och i styrandet av vardagens villkor skapar man nya begrepp som ibland inte heller stämmer med innehållet i vården. I Ädelparadoxen (1998) som behandlar "Sjukhemmen före och efter Ädelreformen" påpekas ett motsvarande fenomen.

Utifrån mitt sätt att begripa retoriken, $\mathrm{i}$ såväl vardagsspråket som i styrningsspråket och glappet däremellan, är gruppboende som omsorgsform för dementa definitivt i försvinnande. Begreppet "gruppboende» däremot, kanske kan hållas levande ännu en tid. Eller som en av de intervjuade tjänstemännen i Portugal uttryckte det: „Om 10-15 år kommer vården av dementa att se likadan ut i Portugal och i Sverige. Vi har gått framåt och ni har gått bakảt, då ni inte kommer att ha pengar till den fina värd ni har byggt uppk.

\section{Referenser}

Adolfsson Rolf,Sandman Per-Olof, Wikander Birgitta (1991) Äldreliv. Psykologi, Psykiatri, Demens, Omvårdnad. Förlaget Hagman, Stockholm

Alvesson Mats (1989) Sociala störningar av självet. Studentlitteratur: Lund

Alvesson Mats, Sköldberg Kaj (1994) Tolkning och reflektion. Vetenskapsfilosofi och kvalitativ metod. Studentlitteratur: Lund

Annerstedt Lena (1988) »Vård och vetande« i Källa 32, Försummad folkssjukdom. Aktuell debatt om Alzheimer och andra demenssjukdomar. Forskningsrådsnämnden, Stockholm

Annerstedt Lena (1995) On group-living care for demented elderly. Institutionerna för klinisk samhällsmedicin och geriatrisk psykiatri, Lunds Universitet (Akad avh)

Bauer Alfredson Betty (1991) Förändringsarbete $i$ äldrevården. Utvärdering av personalutbildning inom institutionsbunden och alternativ äldrevaird. Pedagogiska institutionen, Lunds universitet (Akad avh)

Beck-Friis Barbro (1988) Hemma på Baltzarsgården. Om vård av åldersdementa i gruppboende. Libris, Örebro 5:e uppl

Borell Lena (1992) The Activity Life of persons with a dementia disease. Karolinska institutet: Stockholm (Akad avh)

Colvez A, Ritchie B, Ledésert J, Ankri H, Gardent A (1994) Fontaine-Editions INSERM, France
Egidius Henry (1997) Psykologilexikon. Natur och Kultur, Stockholm

Eliasson-Lappalainen Rosmari (1996) Omsorgens skiftningar. Begreppet, vardagen, politiken, forskningen. Studentlitteratur: Lund

Elmståhl Sölve, Annerstedt Lena, Melin Emilsson Ulla, Samuelsson Sven-Mårten, Åhlund Owe (1993) »Vård - och boendeformer för demenssjuka äldre. För vilka patientkategorier och hur ska gruppboende utformas? "Socialvetenskapliga Forskningsrådet. (Ansökan 1993-01-25)

Fahlström, Gunilla (1999) Ytterst i organisationen. Omundersköterskor, vaird- och sjukvårdsbiträden iäldreomsorg. Uppsala Universitet, Institutionen för folkhälso- och vårdvetenskap. (Akad avh)

Fairclough Norman, (1995) Critical Doscourse Analysis. The critical study of language. Longman: London

Franssén Agneta (1997) Omsorg i tanke och handling. En studie av kvinnors arbete $i$ vairden. Lund: Arkiv Förlag (Akad avh)

Gaunt David, Öhlander Magnus, Schwarz Rickard (1993) Demensvaird. En forskningsöversikt. FoU-byrån, Socialtjänsten, Stockholm

Hallberg Ingalill R, (1990) Vocally Disruptive Behaviour in Severly Demented Patients in Relation to Institutional Care Provided. Umeå University Medical Dissertations (Akad avh)

Johansson Stina (2001) Den sociala omsorgens aka- 
demisering. Liber, Stockholm

Marcusson Jan, Blennow Kaj, Skoog Ingmar, Wallin Anders (1995) Demenssjukdomar. Almqvist \& Wiksell Medicin, Liber utbildning, Stockholm

Melin Emilsson Ulla (1996) „Den blå klänningen. Om privat och offentligt i gruppboenden för dementa" i Eliasson Rosmari (red) Omsorgens skiftningar. Studentlitteratur: Lund

Melin Emilsson Ulla (1998) Vardag i olika världar. Om dementa och vårdbiträden på tre Gruppboenden. Arkiv förlag: Lund (akad avh)

Melin Emilsson Ulla (1999) "Handledning som utbildning och stöd för personal i arbete med äldre demenssjuka - ett utvecklingsprojekt." (RALF- Rådet för Arbetslivsforskning 1999. 0590) Vinnova dnr 2001/03584

Melin Emilsson Ulla (2001a) "A Supervisão como Metodo de Pesquisa em serviço social. Projecto sobre Idosos e Doença Mental na Suecia», Interaççoes, 1 Outubro 50-64

Melin Emilsson Ulla (2001b) "Gammal och dement i Sverige, Portugal och Frankrike - en komparativ studie av socialpolitiska mål och implementering i tre kulturer». Forskningsrådet för Arbetsliv och Socialvetenskap, Dnr 2001-2422

Melin Emilsson, Ulla (2001c) "Möten och relationer i demensvården - om forskning och implementering för utbildning, stöd och utveckling". Tidskriften Vård Nr 1.2001. April, 53-58.

Melin Emilsson Ulla (2002) "Vårdbiträde inom äldreomsorgen. Offer eller kompetent specialist? Äldre i Centrum Nr 2.

Melin Emilsson Ulla (2003a) Handledning och lärande i äldreomsorgens vardag. (Under utgivning på Studentlitteratur, Lund)

Melin Emilsson Ulla (2003b) »Research information in qualitative research: An interactive effort in focus groups". (submitted)

Michela John L (1996) "Social Psychology and Organizations» i (red) Semin R Gün \& Fiedler Klaus Applied Social Psychology. Sage Publications: London

Nystrand Anders (1994) Demens. Apoteken informerar om sjukdom och hälsa, nr 11. Apoteksbolaget, Stockholm

Ritchie Karen, Ledésert Bernard (1992) »The fami- lies of the institutionalized dementing elderly: A preliminary study of stress in a french caregiver population". International Journal of Geriatric Psychiatry7 5-14

Olsson Eric (1998) På spaning efter gruppens själ. Gruppen i teori och praktik. Studentlitteratur, Lund

Socialdepartementet, Ds 1989:27 Ansvaret för Äldreomsorgen. Rapport frän äldredelegationen

Socialstyrelsen (1991) Gruppboende och gruppbostäder för äldre. Huvudrapport. SoS 1991:5

Socialstyrelsen (1998) Ädelparadoxen. Sjukhemmen före och efter Ädelreformen.

Socialstyrelsen (2001) Vad är särskilt $i$ särskilt boende? - En kartläggning

Socialstyrelsen (2002) Nationell handlingsplan för äldrepolitiken. Slutrapport 2002.

Socialstyrelsen (2004) Varför kan inte behovet av särskilda boendeformer tillgodoses.

SOSF 1992:8 Socialstyrelsens föreskrifter och allmänna råd om tillfälligt statsbidrag till anordnande av gruppbostäder och andra alternativa boendeformer.

SOU 1996:2 Ädelreformen. Slutrapport.

SOU 1996:27 En strategi för kunskapslyft och livslångt lärande.

SOU 1997:51 Brister i omsorg - en fräga om bemötande av äldre. Delbetänkande av Utredningen om bemötande av äldre

SOU 1999:97 Äldreomsorg - reglering och uppgifter. Bilaga 4

SOU 2004:91 Vård och omsorg. BilagedelC. Äldrepolitik för framtiden. 100 steg till trygghet och utveckling med en åldrande befolkning. Senior 2005

Svensson Marianne, Edebalk Per Gunnar, Persson Ulf (1996) "Group living for elderly patients with dementia - A cost analysis" Health Policy, 38 83-100

Szebehely Marta (1995) Vardagens organisering. Om vårdbiträden och gamla $i$ hemtjänsten. Arkiv förlag, Lund (Akad avh)

Wimo Anders, Karlsson G, Sandman P O, Winblad B (1994) Vården av dementa - en tickande kostnadsbomb. Förändring av prevalens och kostnader 1980-2025. Rapport 1992:2, Stiftelsen Stockholms läns Äldrecentrum, Stockholm

Ulla Melin Emilsson: Gruppboende för dementa - en omsorgsform eller ett begrepp i försvinnande? 
Vabø Mia (2003) „Mellan traditioner och trender. New Public Management som idé och praktik" i Szebehely Marta (red) Hemhiälp i Norden - illustrationer och reflektioner. Studentlitteratur: Lund

Åhlund Owe, Annerstedt Lena, Elmståhl Sölve, Samuelsson Sven-Mårten (1995) Gruppboende för demenssjuka äldre - en analys av miljöutformning. Lunds universitet, Institutionen för Kliniska Samhällsmedicin, Malmö

Öhlander Magnus (1996) Skör verklighet. En etnologisk studie av demensvaird $i$ gruppboende. Institutet för folklivsforskning, Stockholms universitet (Akad avh)

\section{Summary \\ Group living for demented elderly- the disappearance of an idea or a care form?}

The development of group living for older people suffering from dementia began in Sweden about 25 years ago as an alternative to traditional nursing home care. During a period of ten years from the middle of 1980s the expansion was large. Then, suddenly the developments diminished and so too did the use of the term "group living".

In this article I discuss whether it is group living as care form that is disappearing, or just the conception of the term. By using empirical data from three of my own Swedish studies carried out during this period and one ongoing international project of my own, I compare the way of talking about the term, the form of the care and the content in everyday language and in the steering documents.

This study shows that there is a gap between the two languages: the "everyday language» used by the people working with the elderly suffering from dementia and the "steering language" used in the written documents by officials in leading positions and politicians. In a certain sense this indi- cates two worlds, with two different languages, that never meet. With a social psychological theoretical framework my interpretation is that differences in intentions and ambitions for the care could be a part of the explanation. While caregivers strive to keep the idea of group living alive, both for their own sake and in the interest of the demented elderly, the officials and politicians are in a need of continual change of ideas according to political and economic circumstances.

In the everyday language the objectives are evidently expressed with a constant use of the terms and their significance. However, in the steering language there is a permanently ongoing change of the terms as well as of their meaning. As these changes are only implicitly expressed this also helps to explain the gap between these two worlds. In the light of these findings my conclusion is that group living as a form of care is definitely disappearing in Sweden, and in a few years probably even the term "group living« will vanish. 